\title{
Decolorization of CI Reactive Blue 222 by immobilized basidiomycetes in response to different carbon and nitrogen inputs
}

\author{
(를 Maria Valle Vitali ${ }^{1,4}$, Nara Ballaminut ${ }^{2}$ and Dácio Roberto Matheus ${ }^{2,3}$
}

Received: 8.08.2017; accepted: 24.04.2018

\begin{abstract}
Decolorization of CI Reactive Blue 222 by immobilized basidiomycetes in response to different carbon and nitrogen inputs). Reactive dyes are found in the final effluents of the textile industry and cannot be removed by conventional treatment processes. The use of basidiomycetes appears to be an effective strategy to degrade dye molecules. In this paper, the parameters that favor decolorization of diazo dye were assessed using basidiomycetes immobilized in Luffa cylindrica. Different concentrations of saccharose and urea were assessed, in addition to the introduction of an enriched synthetic effluent. Results showed that the best decolorization occurred at the highest concentration of saccharose and the lowest of urea. It was observed a high biosorptive capacity of the solid support, which decreased when the effluent was enriched with saccharose and urea due to consequent increase in microbial activity. Using the enriched effluent, Pleurotus ostreatus decolorized about $70 \%$ within 48 hours, and Trametes villosa decolorized 58\% after 240 hours. Peniophora cinerea did not respond to the conditions tested.
\end{abstract}

Keywords: azo dye, biodegradation, Pleurotus ostreatus, textile effluents

RESUMO - (Descoloração do corante reativo azul CI222 por basidiomicetos imobilizados em resposta às diferentes entradas de carbono e nitrogênio). Os corantes reativos são encontrados nos efluentes finais da indústria têxtil. Quando esses efluentes são tratados por processos convencionais, os corantes não são removidos. O tratamento que empregou basidiomicetos mostrou ser capaz de degradar a molécula de corante. Neste trabalho avaliou-se parâmetros que favoreceram a descoloração do corante diazo usando basidiomicetos imobilizados sob Luffa cylindrica. Foram avaliadas diferentes concentrações de sacarose e ureia, além da introdução de efluente sintético enriquecido. Os resultados mostraram que a melhor descoloração ocorreu nas maiores concentrações de sacarose e nas menores concentrações de ureia. Observou-se a capacidade de adsorção do suporte sólido, que diminuiu quando o efluente foi enriquecido com sacarose e ureia, devido ao consequente aumento da ação microbiana. Pleurotus ostreatus com efluente enriquecido descoloriu cerca de $70 \%$, dentro de 48 horas e Trametes villosa descoloriu em torno de $60 \%$ após 240 horas. Peniophora cinerea não respondeu às condições testadas.

Palavras-chave: biodegradação, corante azo, efluentes têxteis, Pleurotus ostreatus

\section{Introduction}

There is an extensive variety of synthetic textile dyes that are grouped together according to their similarities in chemical composition and applications, and about $2 / 3$ of them have chromophores of azo groups. The textile reactive ones have significant applications in the market worldwide, due to their broad range of color shades, easy use and low energy consumption in the process. These compounds enter in the textile process through the dying bath, and their efficiency in fiber fixing vary from $60 \%$ to $90 \%$. However, the discharge of colorful effluents to the environment is undesirable, not only due to the presence of color itself, but also for potential carcinogenic and/or mutagenic effects, and formation of toxic products. Additionally, azo groups can break down under reductive conditions to release toxic and hydro-soluble amines which, have increased mobility in the systems and makes, this type of effluent problematic (Aguiar et al. 2010, Zaharia \& Suteu 2012, Kyzas et al. 2013).

The inefficiency of physical and chemical processes has led to the association of these treatments with biological ones, which seem to be promising

1. Instituto de Botânica, Núcleo de Pesquisa em Micologia, 04301-902 São Paulo, SP, Brasil

2. Universidade de São Paulo, Instituto de Ciências Biomédicas, 05508-900 São Paulo, SP, Brasil

3. Universidade Federal do ABC, Centro de Engenharia, Modelagem e Ciências Sociais Aplicadas, 09210-580 Santo André, SP, Brasil

4. Corresponding author: vvitaliibot@gmail.com 
strategies for the removal of residual dyes from wastewaters (Senthilkumar et al. 2012, Kiran et al. 2013, Álvarez et al. 2013, Almeida \& Corso 2014). Fungi, especially basidiomycetes, have various advantages for their application in this kind of treatment, as well as in biodegradation, due to the action of enzymes of the ligninolytic complex, which allow them to catalyze the degradation of different compounds, including dyes (Bibi and Bhatti 2012, Kalpana et al. 2012, Malachova et al. 2013, Moreira-Neto et al. 2013). Neto (2011), assessed the decolorization of the CI Reactive Blue 19 by basidiomycetes, and found that Peniophora cinerea, Pleurotus ostreatus and Trametes villosa, were are able the dye under conditions of high salinity and high $\mathrm{pH}$. These authors observed the most significant decolorization in the in vivo treatment, with a predominance of laccase production (Neto et al. 2011, Moreira-Neto et al. 2013).

In addition, some studies have reported the presence of carbon and nitrogen sources acting as co-substrates, favoring decolorization and stimulating enzyme production (Levin et al. 2010, Andrade et al. 2013, Gahlout et al. 2013). Hou et al. (2004), reported laccase production associated with low nitrogen concentration in culture. Viswanath (2014) considered that the best carbon source for fungi to grow and produce laccase is glucose, whose concentration varies depending on the fungal species used. Mazmanci \& Unyayar (2005) observed the predominance of laccase production during CI Reactive Black 5 decolorization by Furnalia trogii immobilized in $L$. cylindrica, and concluded that high decolorization rates were associated with enzyme production. Pedrosa-Rodriguez and Rodriguez-Vasquez (2013) studied the treatment of Kraft liquor by $T$. versicolor and observed high decolorization associated with enzyme production, including laccase, when the $\mathrm{C} / \mathrm{N}$ ratio was high.

Another important factor to consider in biotechnological processes is the use of a support medium, such as L. cylindrica, which proved to be efficient for immobilizing biomass of filamentous fungi. This efficiency is due to presence of cellulose, hemicellulose and lignin in its fibers, all compounds that inducers the production of lignocellulolytic enzymes, (Mazmanci and Unyayar 2005, Saratale et al. 2011, Saab et al. 2013). Mazmanci and Unyayar (2005) observed that $F$. trogi-immobilized with L. cylindrica showed an increase in the tolerance to high dye concentrations. In addition, a positive decolorization, and a decrease in organic load of effluents from the paper industry were observed using T. versicolor immobilized with polyurethane, in bioreactors (Pedroza-Rodríguez \& RodríguezVázquez 2013).

In this context, the current study aimed at assessing the influence of introducing low-cost nutrient concentrations at different times, during the decolorization of $\mathrm{Cl}$ Reactive Blue 222 by basidiomycetes immobilized with $L$. cylindrica, as well as optimization the fungal metabolism to override the adsorptive capacity of this support.

\section{Material and methods}

Microorganisms -The species Trametes villosa (Sw.) Kreisel CCIBt 2628, Peniophora cinerea (Pers.) Cooke CCIBt 2541 and Pleurotus ostreatus (Jacq.) P. Kumm. CCIBt 2347, obtained from the Collection of Algae, Cyanobacteria and Fungi Cultures of the Institute of Botany (CCIBt) were used in this study. Fungi cultures were maintained in 2\% Malt Extract Agar (MEA), at $25 \pm 2{ }^{\circ} \mathrm{C}$.

Dye - The dye CI Reactive Blue 222, (Golden Technology), was measured in an aqueous solution, and prepared at room temperature with deionized water.

Stage 1: Effect of different saccharose and urea concentrations as nutrient sources.

Culture medium; A basic medium (BM) composed of: $0.049 \mathrm{~g} \mathrm{~L}^{-1} \mathrm{CuSO}_{4} ; 0.2 \mathrm{~g} \mathrm{~L}^{-1} \mathrm{~K}_{2} \mathrm{HPO}_{4} ; 0.05 \mathrm{~g} \mathrm{~L}^{-1} \mathrm{MgSO}_{4}$ and $0.016 \mathrm{~g} \mathrm{~L}^{-1} \mathrm{MnSO}_{4}$, was dissolved in distilled water and, different concentrations of saccharose and urea were added as carbon and nitrogen source respectively (table 1 ).

Culture conditions: fragments of $2 \mathrm{~cm}^{2}$ of Luffa cylindrica, $(3 \pm 0.25 \mathrm{~g})$ were placed into $250 \mathrm{~mL}$ Erlenmeyer flasks, containing, $150 \mathrm{~mL}$ water, and sterilized, in the autoclave, 1 atm of pressure, for 40 minutes. Thereafter, all the water was drained, and $150 \mathrm{~mL}$ BM was added to the system which was sterilized for 15 minutes. Fragments of L. cylindrica remained submerged for 24 hours in the BM, and then the medium was drained completely. Three disks of mycelium grown onto MEA $(\varnothing=0.5 \mathrm{~cm})$ were inserted into the treated L. cylindrica supports. Each cultivation systems was incubated separately for 10 days at $25 \pm 0.2^{\circ} \mathrm{C}$. 
Synthetic effluent: the $\mathrm{NaCl}$ saline solution $\left(30 \mathrm{~g} \mathrm{~L}^{-1}\right)$ was sterilized in the autoclave at $121{ }^{\circ} \mathrm{C}, 1 \mathrm{~atm}$ of pressure, for 20 minutes. After cooled down to $40^{\circ} \mathrm{C}$, the dye solubilized in $0.5 \mathrm{~g} \mathrm{~L}^{-1}$, was added, without adjusting the $\mathrm{pH}$.

Treatment system: at day 10 of incubation, $150 \mathrm{~mL}$ of the synthetic effluent was added to the cultures. Monitoring was done by taking aliquots of the liquid phase at the initial time and after 24 hours. Flasks without fungi were used as abiotic control (CABio) of the support's biosorption capacity, and flasks with fungi were used to evaluate both the biosorption of the support and the ability of fungal biodegradation (decolorization).

Decolorization: the decolorization ability was assessed spectrophotometrically by the decrease in absorbance at $610 \mathrm{~nm}$, accordingly to Moreira Neto et al. (2013).

Data analysis: analyses were made according to a 5 $\times 5$ factorial design, without replicates. Experimental results were assessed with regression analysis and significant differences evaluated with analysis of variance (ANOVA) by using F-distribution (MINITAB, 2016). All percentage data were transformed by using the equation described by Vieira \& Hoffman (1989).

Stage 2: optimization of the decolorization treatment system through selected nutritional conditions and the enriched effluent

Preparation of cultures and of the synthetic effluent was carried out as described previously. Low urea concentrations $(0 \%=\mathrm{N} 1 \mathrm{a}, 0.0056 \%=\mathrm{N} 1 \mathrm{~b}$; $0.0112 \%=\mathrm{N} 1 \mathrm{c}, 0.0211 \%=\mathrm{N} 1 \mathrm{~d})$, were added to the BM medium with a fixing saccharose concentration at $1.2 \%$ (C5). Concomitantly, the influence of the enriched synthetic effluent was assessed by adding nutrients $(1.2 \%$ saccharose and $0.0703 \%$ urea - C5N5 table 1) to the dye solution.

Optimized treatment system: at day 10 of incubation, $150 \mathrm{~mL}$ of the enriched synthetic effluent was added to each culture. Monitoring of the complete treatment systems (STc) and of the fungal action (F) isolated was performed by taking aliquots of the liquid phase at the initial time, after 24, 48 and 240 hours after the addition.

Decolorization: the decolorization was assessed as previously described.

Data analysis: analysis of data was performed through ANOVA and, when significant differences $(p \leq 0.05)$ were observed, the means were compared by Tukey's test, using the program MINITAB v. 2016. All data expressed as percentage were transformed according to Vieira \& Hoffman (1989).

\section{Results}

The results showed that the treatment systems presented from $50 \%$ to $63 \%$ decolorization depending on the nutritional conditions (table 2), and responded differently to the addition of urea and saccharose depending on the fungi specie. For systems employing $P$. ostreatus $(p=0.051)$ e $P$. cinerea $(p=0.085)$, the best decolorization rates occurred in the absence, or yet in the low nitrogen concentrations, (i.e. N1 and N2), but in the case of T. villosa ( $p=0.036)$ occurred at the biggest carbon concentration, (C5).

Regarding STc (complete treatment systems), which considered the biosorption onto the support medium, and onto the fungal biomass, as well as, the associated biodegradation, $P$. ostreatus showed higher decolorization (about 20\%) than the other fungi which decolorized less than $10 \%$. When the fungal action (F), was evaluated separately in relation to nutrients, results were the same as those obtained for the other systems, except in the case of $P$. cinerea, which did not reply to any of them.

The conditions selected in the present study allowed the system overcoming the high biosorption of the support medium, and provided the appropriate conditions for fungal grow, favouring the expression

Table 1. Combination of nutritional concentrations of carbon and nitrogen sources.

\begin{tabular}{lccccc}
\hline Nitrogen concentration (\%) & \multicolumn{4}{c}{ Carbon concentration (\%) } \\
\hline \multirow{2}{*}{0,0} & 0,0 & 0,3 & 0,6 & 0,9 & 1,2 \\
0.01125 & $\mathrm{C} 1 \mathrm{~N} 1$ & $\mathrm{C} 2 \mathrm{~N} 1$ & $\mathrm{C} 3 \mathrm{~N} 1$ & $\mathrm{C} 4 \mathrm{~N} 1$ & $\mathrm{C} 5 \mathrm{~N} 1$ \\
0.03094 & $\mathrm{C} 1 \mathrm{~N} 2$ & $\mathrm{C} 2 \mathrm{~N} 2$ & $\mathrm{C} 3 \mathrm{~N} 2$ & $\mathrm{C} 4 \mathrm{~N} 2$ & $\mathrm{C} 5 \mathrm{~N} 2$ \\
0.05063 & $\mathrm{C} 1 \mathrm{~N} 3$ & $\mathrm{C} 2 \mathrm{~N} 3$ & $\mathrm{C} 3 \mathrm{~N} 3$ & $\mathrm{C} 4 \mathrm{~N} 3$ & $\mathrm{C} 5 \mathrm{~N} 3$ \\
0.07031 & $\mathrm{C} 1 \mathrm{~N} 4$ & $\mathrm{C} 2 \mathrm{~N} 4$ & $\mathrm{C} 3 \mathrm{~N} 4$ & $\mathrm{C} 4 \mathrm{~N} 4$ & $\mathrm{C} 5 \mathrm{~N} 4$ \\
& $\mathrm{C} 1 \mathrm{~N} 5$ & $\mathrm{C} 2 \mathrm{~N} 5$ & $\mathrm{C} 3 \mathrm{~N} 5$ & $\mathrm{C} 4 \mathrm{~N} 5$ & $\mathrm{C} 5 \mathrm{~N} 5$ \\
\hline
\end{tabular}


of ligninolytic enzymes, which consequently, optimized the decolorization. However, up to $80 \%$ of the observed decolorization could be tributed to the biosorptive capacity of L. cylindrica. In this sense, the results indicated that better optimization of the systems was still needed. Other formulations of the culture medium were also evaluated, using low concentrations of urea, according to the requirements of $P$. ostreatus and $P$. cinerea, and maintaining a high saccharose concentration, in order to meet the requirements of T. villosa. The systems evaluated at the second stage presented greater decolorization after 24 hours ( 70 to $78 \%$ ), than at stage 1 . Even when the incubation period was extended up to 240 hours, decolorization only increased in $20 \%$ for $P$. ostreatus, $11 \%$ for $P$. cinerea and $8 \%$ for $T$. villosa, thus demonstrating that during the first 24 hours occurred the highest decolorization.
The species evaluated responded differently to nitrogen concentrations. In the case of $T$. villosa a greater response was observed at the lowest concentrations tested, $(\mathrm{N} 1 \mathrm{bC} 5)$ and $P$. ostreatus responded positively ( $p$ $<0.05$ ) to the highest nitrogen concentration evaluated at stage 2 (N1dC5), while $P$. cinerea did not respond to the conditions tested. However, when the fungal system was compared with the abiotic control, the fungal system provided less decolorization than at stage $1(2 \%$ for $P$. ostreatus and $P$ cinerea, and $7 \%$ for $T$. villosa). These results showed that the new nutrient formulation favoured the biosorption onto the solid support and the fungal biomass.

At stage 1, the high concentrations of both saccharose and urea, favoured the increase in fungal biomass. Thus maximum concentrations of both nutrients used in stage 1 (N5C5) were added to the

Table 2. Decolorization of CI Reactive Blue 222 through treatment systems in vivo employing Pleurotus ostreatus, Peniophora cinerea and Trametes villosa, individually immobilized in Luffa cylindrica.

\begin{tabular}{|c|c|c|c|c|c|c|}
\hline \multirow{3}{*}{ Treatment } & \multicolumn{6}{|c|}{ Decolorization on the systems of in vivo treatment [\%] } \\
\hline & \multicolumn{2}{|c|}{ Pleurotus ostreatus } & \multicolumn{2}{|c|}{ Peniophora cinerea } & \multicolumn{2}{|c|}{ Trametes villosa } \\
\hline & STc & $\mathrm{F}$ & STc & $\mathrm{F}$ & STc & $\mathrm{F}$ \\
\hline C1N1 & 47,98 & 18,03 & 58,13 & 4,16 & 44,56 & 0 \\
\hline $\mathrm{C} 1 \mathrm{~N} 2$ & 38,54 & 8,6 & 44,8 & 0 & 50,35 & 5,1 \\
\hline C1N3 & 46,17 & 16,23 & 41,28 & 0 & 44,62 & 0 \\
\hline C1N4 & 27,39 & 0 & 55,24 & 1,26 & 45,16 & 0 \\
\hline C1N5 & 45,69 & 15,74 & 41,96 & 0 & 48,84 & 3,59 \\
\hline $\mathrm{C} 2 \mathrm{~N} 1$ & 28,2 & 0 & 47,25 & 0 & 49,45 & 4,19 \\
\hline $\mathrm{C} 2 \mathrm{~N} 2$ & 43,47 & 13,53 & 46,51 & 0 & 0 & 4,75 \\
\hline $\mathrm{C} 2 \mathrm{~N} 3$ & 48,9 & 18,95 & 13,67 & 0 & 46,44 & 1,19 \\
\hline $\mathrm{C} 2 \mathrm{~N} 4$ & 8,06 & 0 & 44,85 & 0 & 44,55 & 0 \\
\hline C2N5 & 34,77 & 4,82 & 52,91 & 0 & 42,88 & 0 \\
\hline C3N1 & 28,51 & 0 & 51,21 & 0 & 45,45 & 0,2 \\
\hline $\mathrm{C} 3 \mathrm{~N} 2$ & 46,8 & 16,86 & 49,62 & 0 & 50,14 & 4,89 \\
\hline $\mathrm{C} 3 \mathrm{~N} 3$ & 41,18 & 11,24 & 55,81 & 1,84 & 50,27 & 5,01 \\
\hline C3N4 & 43,5 & 13,56 & 48 & 0 & 45,57 & 0,32 \\
\hline C3N5 & 33,73 & 3,78 & 39,75 & 0 & 46,96 & 1,71 \\
\hline C4N1 & 45,87 & 15,92 & 63,67 & 9,7 & 49,79 & 4,54 \\
\hline C4N2 & 54,49 & 24,55 & 50,4 & 0 & 53,14 & 7,89 \\
\hline C4N3 & 41,18 & 7,57 & 38,55 & 0 & 42,72 & 0 \\
\hline C4N4 & 43 & 13,06 & 44,25 & 0 & 48,18 & 2,92 \\
\hline C4N5 & 41,66 & 11,71 & 25,74 & 0 & 46,28 & 1,03 \\
\hline C5N1 & 17,77 & 0 & 59,56 & 5,59 & 54 & 8,74 \\
\hline $\mathrm{C} 5 \mathrm{~N} 2$ & 47,99 & 18,04 & 55,56 & 1,58 & 50,74 & 5,48 \\
\hline C5N3 & 37,51 & 22,46 & 49,36 & 0 & 50,99 & 5,74 \\
\hline C5N4 & 17,34 & 0 & 54,16 & 0,19 & 47,41 & 2,16 \\
\hline C5N5 & 14,64 & 0 & 52,38 & 0 & 54,18 & 8,92 \\
\hline
\end{tabular}


synthetic effluent in an attempt to favour fungal metabolism. All evaluated treatments showed a reduction in the dye adsorption by the support medium, regardless of the nitrogen concentration in the culture. The systems with P. ostreatus and T. villosa responded positively $(p<0.05)$ to the decolorization, according to the formulation of the synthetic effluent and the contact time (figure 1). P. ostreatus (figure 1a)
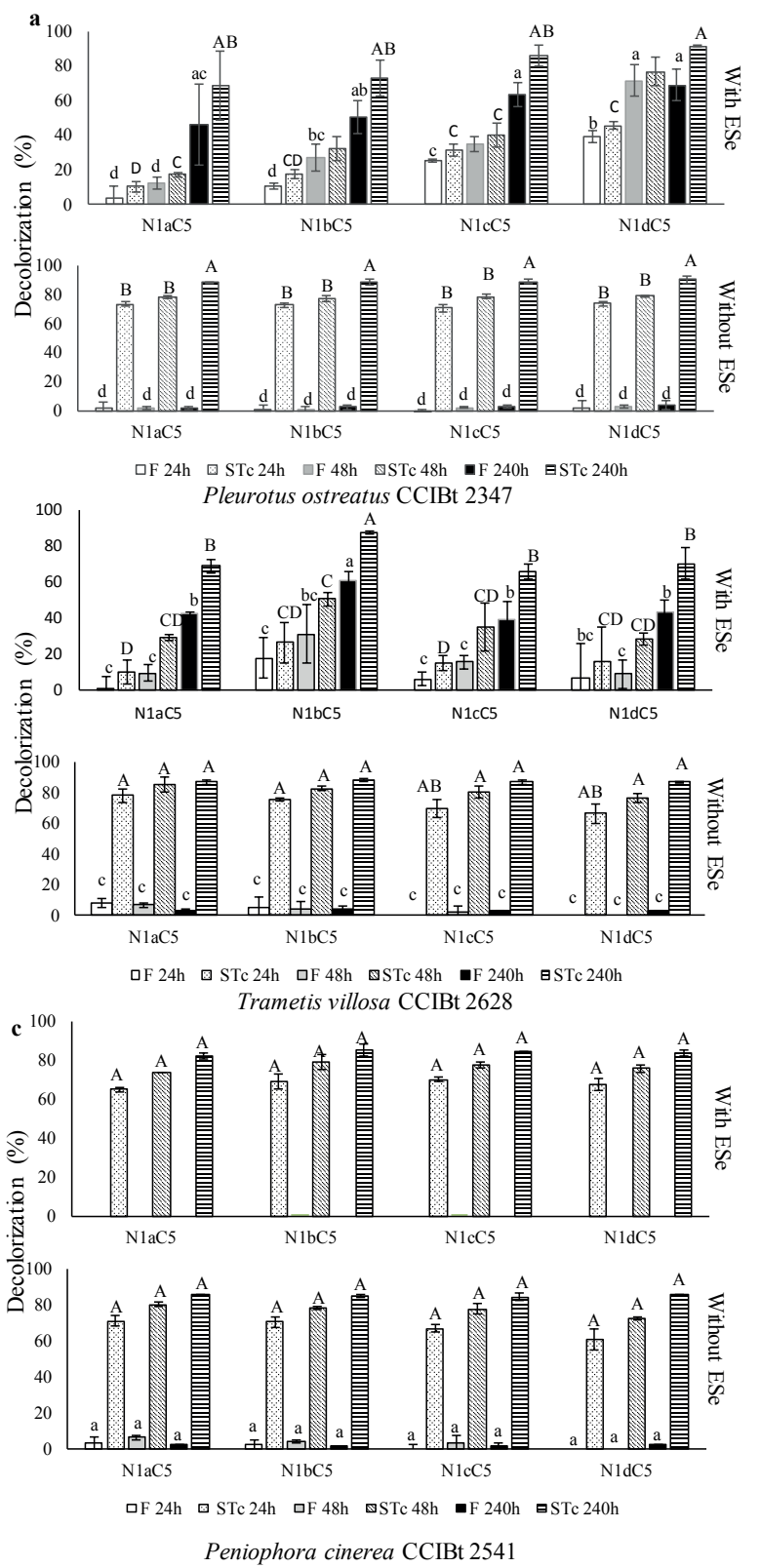

Figure 1. Comparison ofthe effect of nutrients in the CI Reactive Blue 222 in vivo decolorization employing Pleurotus ostreatus CCIBt 2347 (a), Trametes villosa CCIBt 2628 (b) and Peniophora cinerea CCIBt 2541 (c), with and without nutritional additive in (ESe), up to 240 hours of incubation, in the systems of complete treatment $(\mathrm{STc})$ and treatment without the abiotic effect of the control (F). and $T$. villosa (figure $1 \mathrm{~b}$ ) became more efficient under this new culture conditions due to an increased availability of free dye in the liquid phase, and also to the nutrients added to the effluent that might have favoured the ligninolytic metabolism.

$P$. ostreatus showed the highest decolorization rate $(76.39 \%)$, in 48 hours when the abiotic control was discounted $(71.30 \%)$, or when used in the nonenriched effluent, after 240 hours $(89.76 \%)$, although these differences were not significant $(p \geq 0,05)$. This fact indicates that the degradative metabolism of this fungus was able to match the adsorptive capacity of the immobilization support (figure 1a), and showed a positive effect on the decolorization with the increase in nitrogen concentration (figure $1 \mathrm{a}, p=0.00$ ). In contrast, T. villosa presented greater decolorization, (61.12\%), at the lowest nitrogen concentration (N1bC5), associated with a longer contact time. Decolorization by $T$. villosa-STc was $87.58 \%$, similar to those registered when non-enriched effluent was used $(88.05 \%)$. $P$. cinerea showed $85 \%$ of decolorization, in the presence of the non-enriched effluent, but in a longer contact time ( 240 hours). This fungus either exhibited the best decolorization responses after 48 hours, in the absence of nitrogen $(6.17 \%)$ or at the lowest concentration evaluated (4.16\%). The decolorization observed in the treatment with the enriched effluent was equal to the decolorization in the abiotic control. Therefore, the introduction of nitrogen into the culture, or into the effluent, did not stimulated the development of the degradation metabolism of this fungus. In this case, observed that the main action for decolorization was biosorption, presenting from 70 to $85 \%$ of decolorization, in the period considered while the highest percentage of decolorization occurred in the first 24 hours, and approximately $10 \%$ in a longer contact time (figure 1c).

All the treatments showed a decrease in absorbance at $610 \mathrm{~nm}$. However, the absorption spectra of the liquid phase that contained the enriched effluent and used $P$. ostreatus and T. villosa, exhibited a hypsochromic shift of the maximum absorption wavelength from $610 \mathrm{~nm}$ to $526 \mathrm{~nm}$ (figure 2), which indicated transformation of the dye molecule. In the case of $P$. cinerea systems, it was observed the disappearance of all absorption peaks of the absorption spectrum, which might be related to a possible biosorptive action.

\section{Discussions}

Previous studies have also shown that each fungal strain responds differently to the nutritional 
concentrations, Akdogan et al. (2014), evaluated the anthraquinone dye CI Reactive Blue $19\left(0.05 \mathrm{~g} \mathrm{~L}^{-1}\right)$ treated by Coprinus plicatilis, and observed $80 \%$ decolorization in cultures that had received $5 \mathrm{~g} \mathrm{~L}^{-1}$ of urea, after 5 days of incubation. Koyani et al. (2013) also observed a high percentage of decolorization of the dye CI Reactive Yellow $145\left(0.01 \mathrm{~g} \mathrm{~L}^{-1}\right)$, treated by Phanerochaete chrysosporium in the presence of $0.01 \mathrm{~g} \mathrm{~L}^{-1}$ of urea. On the other hand P. chrysosporium exhibited high decolorization (97\%) of diazo dye

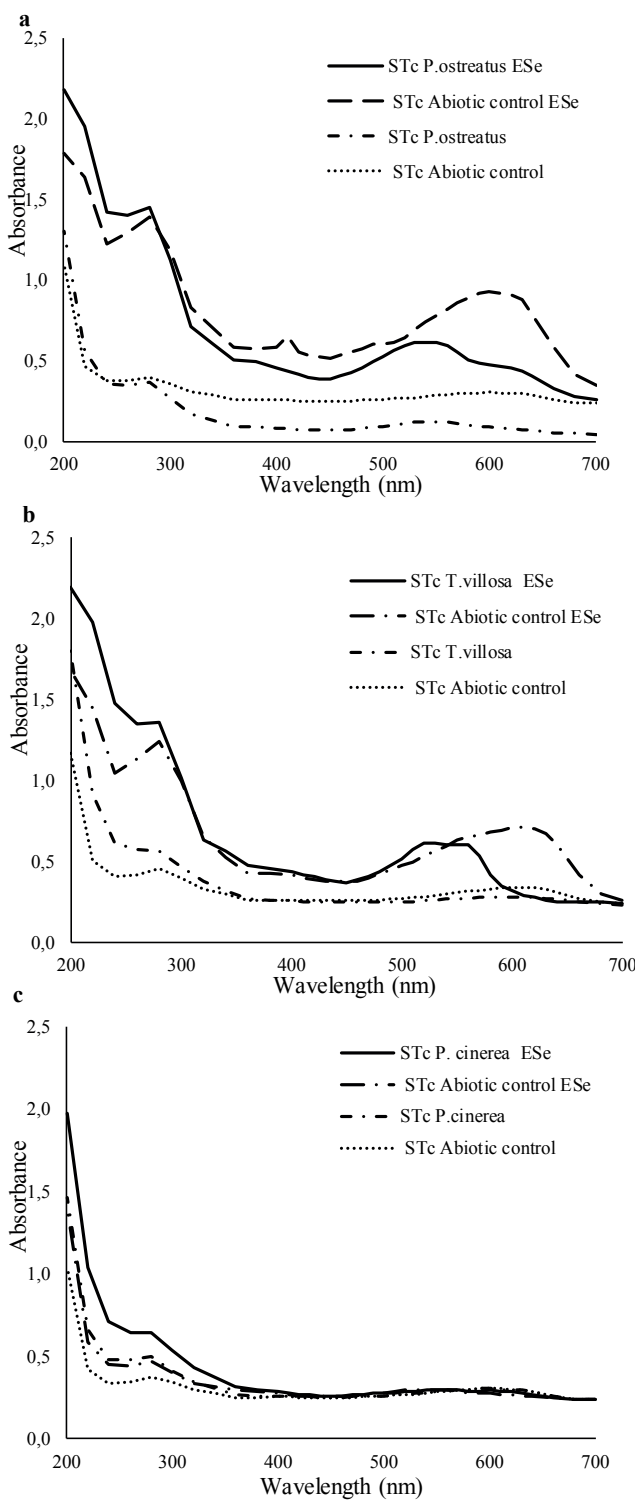

Figure 2: Spectrum of absorption of effluents containing CI Reactive Blue 222, in treatment systems of improved nutritional condition, employing Pleurotus ostreatus CCIBt2347 (a), Trametes villosa CCIBt2628 (b) and Peniophora cinerea CCIBt2541, after 240 hours of incubation, comparing to complete treatment systems (STc) and treatment systems without the abiotic effect of the control $(\mathrm{F})$. $\left(0.05 \mathrm{~g} \mathrm{~L}^{-1}\right)$ in the presence of the saccharose and absence of urea Andrade et al. (2013).

The results these studies indicated that $80 \%$ decolorization was associated with the high biosorptive capacity of $L$. cylindrica, as previously documented (Altınış1k et al. 2010, Cherifi et al. 2013, Saab et al. 2013, Yu et al. 2013). However, Enayatizamir et al. (2011) also suggested a positive influence of the ligninolytic support which defines the type and proportion of the enzymes produced, favoring the expression of the enzymes that are necessary for the decolorization process.

By incorporating saccharose and urea to the synthetic effluent, the activity of basidiomycetes became more efficient, leading to the transformation of the dye molecule. These nutrients ensure favorable nutritional conditions for ligninolytic metabolism, in addition to decreasing the adsorptive capacity of L. cylindrica. Consequently, large quantities of free dye become available in the liquid phase to the in vivo systems. Saccharose promoted growth and activated fungal metabolism, by creating high acidity conditions in the culture medium, which favoured dye degradation (Garg \& Tripathi 2017). According to Asgher (2013), the enriched effluent, is able to modify the chemical and physical properties of the biossorbent due to the activation or deactivation of the support's surface functional groups, and thus the biosorption is decreased.

A hypsochromic shift of the maximum absorption wavelength $\left(\lambda_{\max }\right)$ from $610 \mathrm{~nm}$ to $526 \mathrm{~nm}$, was observed in the absorption specters of the liquid phase of the systems using $T$. villos $a$ and $P$. ostreatus after receiving the enriched effluent. Similarly, Mazmanci \& Unyayar (2005) studied the methylene blue treatment employing Trametes versicolor, and observed a hypsochromic displacement from $597 \mathrm{~nm}$ to 562 and $523 \mathrm{~nm}$. According to Kaushik \& Malik (2009) displacement of $\lambda_{\text {max }}$ may arise from the cleavage of the dye chromophore center and, depending on the cleavage, the removal of $\lambda_{\text {max }}$ can be either partial or complete. On the other hand, according to Zaharia and Suteu (2012), color of synthetic dyes is due to the presence of chromogene-chromophores structures, which are the electron acceptors, and coloring capacity of dyes is due to the auxochrome groups, the donors of electrons, and, as such, able to be ionized. Thus, considering such reactive molecules, the dyes oxidation caused by the ligninolytic enzymes of the fungus may have changed the conformation of the dye molecule resulting in a change of color in the more visible region. 
According to Ciullini et al. (2008) laccases are specific to the dye substrate and to certain chemical structures, mainly due to differences in the distribution of electrons, load density and spatial structure of the molecule, which in turn influences decolorization rates. These authors evidenced the fungal capacity of degrading antraquinones by using a simple mix of two laccase isoenzymes in the absence of a redox mediator, under optimum enzyme concentrations, and conditions of temperature and $\mathrm{pH}$. Moreira Neto et al. (2013), studied the decolorization of the anthraquinone dyes Cibacron Brilliant Blue H-GR by same fungal species and observed the presence of laccase activity in all cultures. In the case of CI Reactive Blue 222, the diazo dye used in the present study, Zollinger (2003).observed partial degradation, which might indicate that oxidation occurred in the weaker position of the connections. Ballaminut (2017) also evaluated decolorization of this dye employing the same fungi in similar culture and observed laccase production, suggesting a positive correlation between the presence of this enzyme and the discoloration registered during the process. Laccases are able to modify the azo structures, destruct their chromophore groups, and simultaneously generate phenoxyl radicals. Firstly, an electron is abstracted from the ring generating a phenoxyl radical, and the abstraction of a second electron generates an aromatic cation, which can be stabilized by the donors groups that are present in the ring. Laccases are not able oxidize the analogous compounds replaced in the molecule, at the meta position, in isolation, once the strength of the enzyme activation at that position is low. The removal of electrons replaced by halogen groups, or by one nitro group, in the aromatic rings, prevents the formation of cationic radical and, consequently, can inhibit or hinder degradation of this kind of dye (Ciullini et al. 2008).

These results demonstrated the ability of the fungi analyzed to transform the dye molecule when conditions are favorable for fungal metabolism, in this case, through the addition of nutrients to the synthetic effluent that minimized both the physiological stress of fungi and dye biosorption to the support. The efficiency of the proposed treatment can be still optimized by adding mediators to the synthetic effluent, in order to extend the catalytic action of the enzyme and act in different patterns of replacements (Amansa et al. 2004).

The results of this study also evidenced that, under particular conditions, the fungal activity can be equal or even superseed the biosorption activity of $L$. cylindrica. Therefore, the study presented a promising biotechnological proposal for the treatment of textile effluents in which a biological system is combined with biosorption and biodegradation, with minimum formation of residues once the solid substrate is biodegradable.

\section{Acknowledgements}

Senai-SP for logistic support, and CNPq scholarship for $\mathrm{PhD}$ student.

\section{Literatura citada}

Aguiar, A., Mendonça R., Rodriguez \& J., Ferraz A. 2010. Behavior of Ceriporiopsis subvermispora during Pinus taeda biotreatment in soybean-oil-amended cultures. Int. Biodeterior. Biodegradation 64: 588-593.

Akdogan, H.A., Topuz, M. C. \& Urhan, A.A. 2014. Studies on decolorization of reactive blue 19 textile dye by Coprinus plicatilis. Journal of Environmental Health Science and Engineering 12: 1-7.

Almeida, E.J.R. \& Corso, C.R. 2014. Comparative study of toxicity of azo dye Procion Red MX- 5B following biosorption and biodegradation treatments with the fungi Aspergillus nigerand Aspergillus terreus. Chemosphere 112: 317-322.

Álvarez, M.S., Moscoso, F., Rodríguez, A., Sanromán, M.A. \& Deive, F.J. 2013. Novel physico-biological treatment for the remediation of textile dyes-containing industrial effluents. Bioresour Technol 146: 689-95.

Altinişik, A., Gür, E. \& Seki, Y. 2010. A natural sorbent, Luffa cylindrica for the removal of a model basic dye. J. Hazard. Mater., 179: 658-664.

Almansa, E. , Kandelbauera, A., Pereira, L., CavacoPaulo, A. \& Guebitz, G.M. 2004. Influence of structure on dye degradation with laccase mediator systems. Biocatal. Biotransform. 22: 315-324.

Andrade, M.V.F. , Silva, K.M.L., Siqueira, J.P.S., Wanderley, C.R.P., Araújo, R.S., Marinho, G. \& Rodrigues, K. 2013. Azo Dye Degradation by Phanerochaete chrysosporium in the Medium Enriched with Nitrogen in the Presence of Primary Co-Substrate. Braz. Arch. Biol. Technol. 56: 867-874.

Asgher, M., Yasmeen, Q. \& Iqba, H.M.N. 2013. Enhanced decolorization of Solar brilliant red 80 textile dye by an indigenous white rot fungus Schizophyllum commune IBL-06. Saudi Journal of Biological Sciences. 20: $347-352$.

Ballaminut, N. 2017. Caracterizaçãodo processo de descoloração de corante reativo diazo por basidiomicetos tropicais Tese de Doutorado, Universidade de São Paulo, São Paulo. 
Bibi, I. \& Bhatti, H.N. 2012. Enhanced Biodecolorization of Reactive Dyes by Basidiomycetes Under Static Conditions. Applied Biochemistry and Biotechnology 166: 2078-2090.

Cherifi, H., Fatiha, B.\& Salah, H. 2013. Kinetic studies on the adsorption of methylene blue onto vegetal fiber activated carbons. Applied Surface Science 282: 52-59.

Ciullini, I., Tilli, S., Scozzafava, A. \& Briganti, F. 2008. Fungallaccase, cellobiose dehydrogenase, and chemical mediators:combined actions for the decolorization of different classesof textile dyes. Bioresource Technology 99: 7003-7010.

Enayatizamir N, Tabandeh F, Rodríguez-Couto S, Yakhchali B, Alikhani H.A. \& Mohammadi L. 2011. Biodegradation pathway and detoxification of the diazo dye Reactive Black 5 by Phanerochaete chrysosporium. Bioresource Technology 102: 10359-62.

Gahlout, M., Gupte, S. \& Gupte, A. 2013. Optimization of culture condition for enhanced decolorization and degradation of azo dye reactive violet 1 with concomitant production of ligninolytic enzymes by Ganoderma cupreum AG-1. 3 Biotech 3: 143-152.

Garg, S. K. \& Tripathi M. 2017. Microbial Strategies for Discoloration and Detoxification of Azo Dyes from Textile Effluents. Research Journal Microbiology 12:1-19.

Hatakka, A. 2005. Biodegradation of lignin. In: Alexander S (ed) Biopolymers Online, Weinheim, Germany: WILEY-VCH Verlag GmbH\& Co. KGaA

Kaushik, P. \& Malik, A. 2009. Fungal dye decolourization: Recent advances and future potential. Environment International 35: 127-141.

Kalpana D., Velmurugan, N., Shim, J.H. , Byung-Taek Oh , Senthil, K. \& Lee, Y.S. 2012. Biodecolorization and biodegradation of reactive Levafix Blue E-RA granulate dye by the white rot fungus Irpex lacteus. J. Environ. Manage 111: 142-149.

Kiran, S., Ali, S. \& Asgher, M. 2013. Degradation and mineralization of azo dye reactive blue 222 by sequential Photo-Fenton's oxidation followed by aerobic biological treatment using white rot fungi. Bull Environ Contam Toxicol 90: 208-15.

Knezevic' A., Milovanovic' I., Stajic' M., Loncar N., Brceski I., Vukojevic' J. \& Cilerdzic' J. 2013. Lignin degradation by selected fungal species. Bioresour. technol. 138: 117-123.

Koyani, R. D., Sanghvi, G.V., Sharma, R.K. \& Rajput, K.S. 2013. Contribution of lignin degrading enzymes in decolourisation and degradation of reactive textile dyes. International Biodeterioration \& Biodegradation 77: 1-9.

Kyzas, G.Z., Kostoglou, M., Lazaridis, N.K. \& Bikiaris D.N. 2013. Decolorization of Dyeing Wastewater Using Polymeric Absorbents - An Overview. In: Eco-Friendly Textile Dyeing and Finishing ed.Intech, M.Günay, pp. 177-206.
Levin, L., Melignani, E.\& Ramos, A. M. 2010. Effect of nitrogen sources and vitamins on ligninolytic enzyme production by some white-rot fungi. Dye decolorization by selected culture filtrates. Bioresource Technology 101: 4554-4563.

Malachova, K., Rybkova, Z. , Sezimova, H., Cerven, J. \& Novotny, C. 2013. Biodegradation and detoxification potential of rotating biological contactor (RBC) with Irpex lacteus for remediation of dye-containing wastewater. Water Research 47: 7143-7148.

Mazmanci, M. A. \& Unyayar, A. 2005 Decolourisation of Reactive Black 5 by Funalia trogii immobilised on Luffa cylindrica sponge. Process Biochemistry 40: 337-342.

Moreira-Neto, S.L., Mussatto, S.I., Machado,K.M.G. \& Milagres A.M.F. 2013. Decolorization of salt-alkaline effluent with industrial reactive dyes by laccaseproducing basidiomycetes strains. Letters in Applied Microbiology 56: 283-290.

Neto, S.L.M., Esteves, P.J., Santos, V.T.O., Paranhos, A.P., Cescato, F., Vitali, V.M. \& Machado, K.M.G. 2011. Novel salt and alkali tolerant neotropical basidiomycetes for dye decolorisation in simulated textile effluent. World Journal of Microbiology and Biotechnology 27: 2665-2673.

Pedroza-Rodríguez, A. M. \& Rodríguez-Vázquez, R. 2013 Optimization of C/N Ratio and Inducers for Wastewater Paper Industry Treatment Using Immobilized in Bubble Column Reactor. Journal of Mycology. Available in em http://www.hindawi.com/ archive/2013/536721/ref/ (access em 04-VIII-2017).

Saab, H.B., Fouchard, S., Boulanger, A., Llopiz, P. \& Neunlist, S. 2013. Luffa cylindrica and phytosterols bioconversion: from shake flask to jar bioreactor. Journal of Industrial Microbiology \& Biotechnology 40: 1315-1320.

Saratale, G.D., Saratale, R.G., Chang, J.S. Govindwar S.P. 2011. Fixed- bed decolorization of Reactive Blue 172 by Proteus vulgaris NCIM- 2027 immobilized on Luffa cylindrica sponge. International Biodeterioration \& Biodegradation 65: 494-503.

Senthilkumar, S., Basha, C.A., Perumalsamya, M. \& Prabhu H.J. 2012. Electrochemical oxidation and aerobic biodegradation with isolated bacterial strains for dye wastewater: Combined and integrated approach. Electrochimica Acta 77: 171-178.

Vieira. S. \& Hoffmann, R. 1989. Estatística Experimental. Atlas, São Paulo.

Viswanath, B., Rajesh, B., Janardhan, A., Kumar, A.P. \& Narasimha G. 2014. Fungal laccases and their applications in bioremediation. Enzyme Research. Available in https://www.researchgate. net/publication/262843177_Fungal_Laccases_and Their_Applications_in_Bioremediation (access in 04-VIII-2017). 
Wong, D. W. S. 2009. Structure and action mechanism of ligninolytic enzymes. Applied Biochemistry and Biotechnology157: 174-209.

Yu, J.-X., Wang, L.-Y., Chi, R.-A., Zhang, Y.-F., Xu, Z.G. \& Guo, J. 2013. Removal of cationic dyes: basic magenta and methylene blue from aqueous solution by adsorption on modified loofah. Research on Chemical Intermediates 39: 3775-3790.
Zaharia,C.\&Suteu,D.2012. TextileOrganic Dyes-Characteristics, Polluting Effects and Separation/Elimination Procedures from Industrial Effluents - ACritical Overview. In: Organic Pollutants Ten Years After the Stockholm Convention-Environmental and Analytical Update. Puzyn, Romênia, pp.55-87.

Zollinger, H. 2003. Color Chemistry. Syntheses, Properties, and Applications of Organic Dyes and Pigments ed. John Wiley \& Sons Zürich:Verlag Helvetica Chimica Acta. 